\title{
THE DISINTEGRATION OF SETTLEMENTS IN BOSNIA AND HERZEGOVINA - THE EXAMPLE OF SARAJEVO/EAST SARAJEVO
}

DOI: http://dx.doi.org/10.18509/GBP.2017.25

UDC: 911.372.9(497.15)

\author{
Mariana Lukić Tanović ${ }^{1}$ \\ Draško Marinković ${ }^{2}$ \\ ${ }^{1}$ University of East Sarajevo, Republic of Srpska - Bosnia and Herzegovina \\ ${ }^{2}$ University of Banja Luka, Republic of Srpska - Bosnia and Herzegovina
}

\begin{abstract}
There were some big political, economic, demographic and administrative changes in Bosnia and Herzegovina primarily caused by the war in the period from 1992 to 1995 Bosnia and Herzegovina is divided into two entities - the Federation of Bosnia and Herzegovina and Republic of Srpska. The entity's boundary did not respect the boundaries of settlements system, and did not respect the boundaries of the settlements itself as the network of settlements, which led to the division of settlements between the two entities. It was perhaps one of the biggest problems when it comes to the data comparability of population census in 1991 and 2013. It can be said that it is almost impossible to determine which number of inhabitants of these divided settlements in 1991 lived on the territory of the Republic of Srpska and which lived in the Federation of Bosnia and Herzegovina. Major changes and disintegration settlements occurred in the area of the capital city of the Bosnia and Herzegovina- Sarajevo, where, in 1992, the city of East Sarajevo is founded. The work will present the kind of changes that occurred at the area of Sarajevo - East Sarajevo, what happened to the settlement system and how it creates problems regarding the comparability of the census. The aim is to point out the level of disintegration of settlements in the researched area.
\end{abstract}

Keywords: Sarajevo, East Sarajevo, disintegration settlements, census

\section{INTRODUCTION}

The formation of a settlement system in Bosnia and Herzegovina is a long historical process which took place under very specific political and social conditions. According the census from 1991 in Bosnia and Herzegovina were 5825 settlements, of which 5572 were in the category of other settlements, and settlements or smaller settlements of the transition type which makes $95.7 \%$ of the total number of settlements, while 253 settlements belonged into the category of urban settlements and it makes $4.3 \%$ of the total. At the end of the twentieth century the Balkan peninsula went through a difficult period of the war that was followed by the political, economic and demographic changes. After the war in Bosnia and Herzegovina (1992-1995) and the signing of the Dayton Peace Agreement in November in 1995, Bosnia and Herzegovina is divided into two entities: the Federation of Bosnia and Herzegovina, with $51 \%$ of pre-war territory and the Republic of Srpska, with $49 \%$ of pre-war territory [3].

The entity boundary did not respect the boundaries of settlements system, and did not respect the boundaries of settlement itself and the network of settlements, which led to the division of settlements between the two entities. (Figure 1 [9]) 


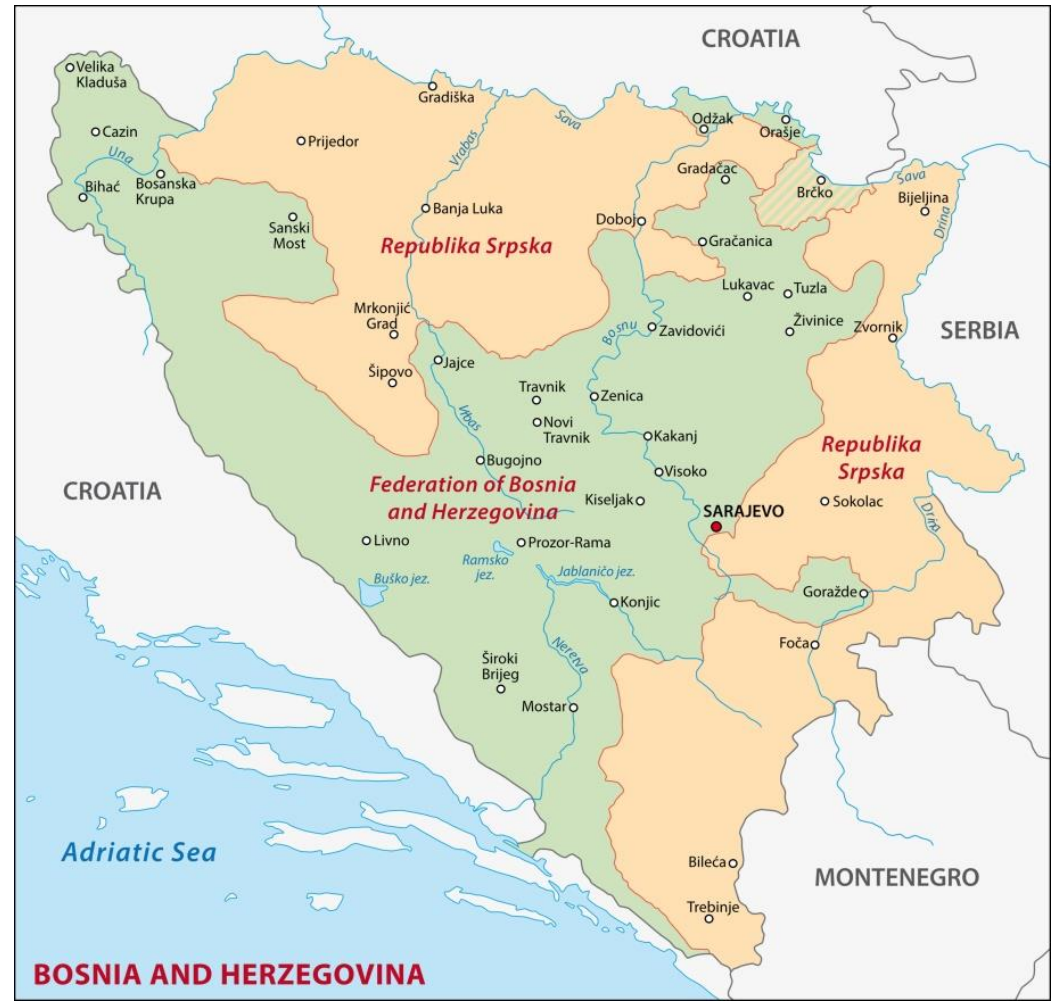

Figure 1. Bosnia and Herzegovina divided in two entites the Federation of Bosnia and Herzegovina and Republic of Srpska

The Paper, at first, through Chapter disintegration of settlements in Bosnia and Herzegovina, will present this problem at the level of state and entities, by method of analysis and synthesis of the available literature, scientific papers dealing with the topic of a settlement system in Bosnia and Herzegovina and the Republic of Srpska. Then, it will explain through the example of section Sarajevo - of East Sarajevo by method of classification and comparison of data on population and settlements according to census from 1991 and 2013 in detail the disintegration of the settlement in this area. For visualization of this studied problem it will be used graphic, tabular, cartographic method.

\section{DISINTEGRATION OF SETTLEMENTS IN BOSNIA AND HERZEGOVINA}

Bosnia and Herzegovina is based on a completely new constitutional-legal and state-legal system as a decentralized state with two entities and central institutions that are vital for the functioning of an internationally recognized state. Considering that Bosnia and Herzegovina is divided into two parts with respect to ethnic and military-political criteria, there was a disintegration of long-hierarchical functional, social, infrastructural and other ties between the large urban centers, the centers of the lower hierarchical rank and their hinterland [5].

In socio-geographical terms, the entity border of settlements has built a system that was created many years in the specific historical and socio-economic conditions. Urban Network of Bosnia and Herzegovina had almost no role in the demarcation of the entity. Considering the complexity of the political and administrative territorial division of of Bosnia and Herzegovina it is understandable that there has been a the split into network of settlements. Entity border has divided 304 settlements [6].

Spatial process of disintegration of settlement is the most pronounced in the northeastern parts of of Bosnia and Herzegovina, in the metropolitan area of Sarajevo, Gorazde and 
Jajce. Viewed the ratio of the total number of settlements in 1991 and the number of divided settlements, the highest degree of disintegration occurs in the northern part of of Bosnia and Herzegovina (Odžak, Gradačac). The disintegration processes of settlement system the most affected the settlement in the category up to 2000 inhabitants $(93.4 \%$ divided settlements). Another factor of the transformation of a settlement system in Bosnia and Herzegovina is present on the administrative-functional plan, or in the case of newly established municipalities in the zone of entity borders of settlements which are classified as rural or the settlement of transitional type growing into political center of the municipality by political decisions. As a conclusion it has been imposed that the political sphere is not planned and rational necessity had a decisive influence on these changes in the spatial-functional organization of the a settlement system in of Bosnia and Herzegovina [5].

The weakening of the demographic potential direct impacts on the established network and of settlements system which functionality weakens changing spatial relations. The changes made in the network of settlements point to a weakening of spatial-functional relationships and bond and the vulnerability of the overall sustainability of the geographic space. The settlement system in the Republic of Srpska and in Bosnia and Herzegovina, has experienced great devastation and fundamentally changed the demographic, functional and infrastructural features, by which the spatial and functional connections and relations have been weakened and broken which affects the future development of the space [4].

\section{EXAMPLE OF THE CITY OF SARAJEVO - EAST SARAJEVO}

Sarajevo or East Sarajevo, is a very good example of disintegrative process, because in this area were divided as many as 43 settlements.

In this area, the supremacy of political reasoning comes up to the maximum over rational and functional need for spatial and functional organization of an urban area. Modern political-territorial structure is radically decompose the space metropolitan area, destroying the system of settlements, infrastructure and economic-social elements established in its long-term development [5].

So they created two parallel uglinesses, unequal political, demographic, economic and cultural powers. When creating such a political solution, the International Community has not adhered to the principle of balance of power, one of the important principles in the demarcations sides in the conflict [7].

From 10 parts of the former municipalities of the City of Sarajevo in the Federation of Bosnia and Herzegovina the Canton Sarajevo was formed from municipalities Stari Grad, Centar, Novo Sarajevo, Novi Grad, Ilijas, Hadzici, Ilidza, Trnovo and Vogosca, and from parts of the municipalities of Stari Grad, Novo Sarajevo, Ilidza, Trnovo and Pale was formed the City of East Sarajevo in the Republic of Srpska, where the municipality of Sokolac is connected too (Figure 2).

On the investigated area particularly specific is Dobrinja, a part of the municipality of Sarajevo named Novi Grad, which was one of the the largest municipalities of Sarajevo before war and the third by population in Bosnia and Herzegovina. Because of the large number of inhabitants (1991 Census - 136616 inhabitans) and because of housing settlement it was divided into Dobrinja I, II, III, IV and V. Because of the specific situation within the war operations, Dobrinja represented a crucial and strategically important area, and after the signing of the Peace Agreement, there was a controversial and unclear situation regarding the demarcation of the eastern part of the settlements. 
There were a series of weaknesses, and inter area of Dobrinja I and IV there was peace line of demarcation from 1995 year that divides buildings and residential buildings which is unacceptable from any reasonable point of view. It is stated that the problem is probably caused by the cartographic presentation of MLR in this area (scale 1: 600000 and 1: 500 000). In 2001, an arbitration decision was made on the inter-entity demarcation in the area of Dobrinja on the detriment of East Sarajevo, after which the pre-war of 1 150 houses and about 300 new buildings were given to Federation of Bosnia and Herzegovina (864 apartments and 84 commercial spaces) and to Republic of Srpska about 370 apartments and 26 commercial space.

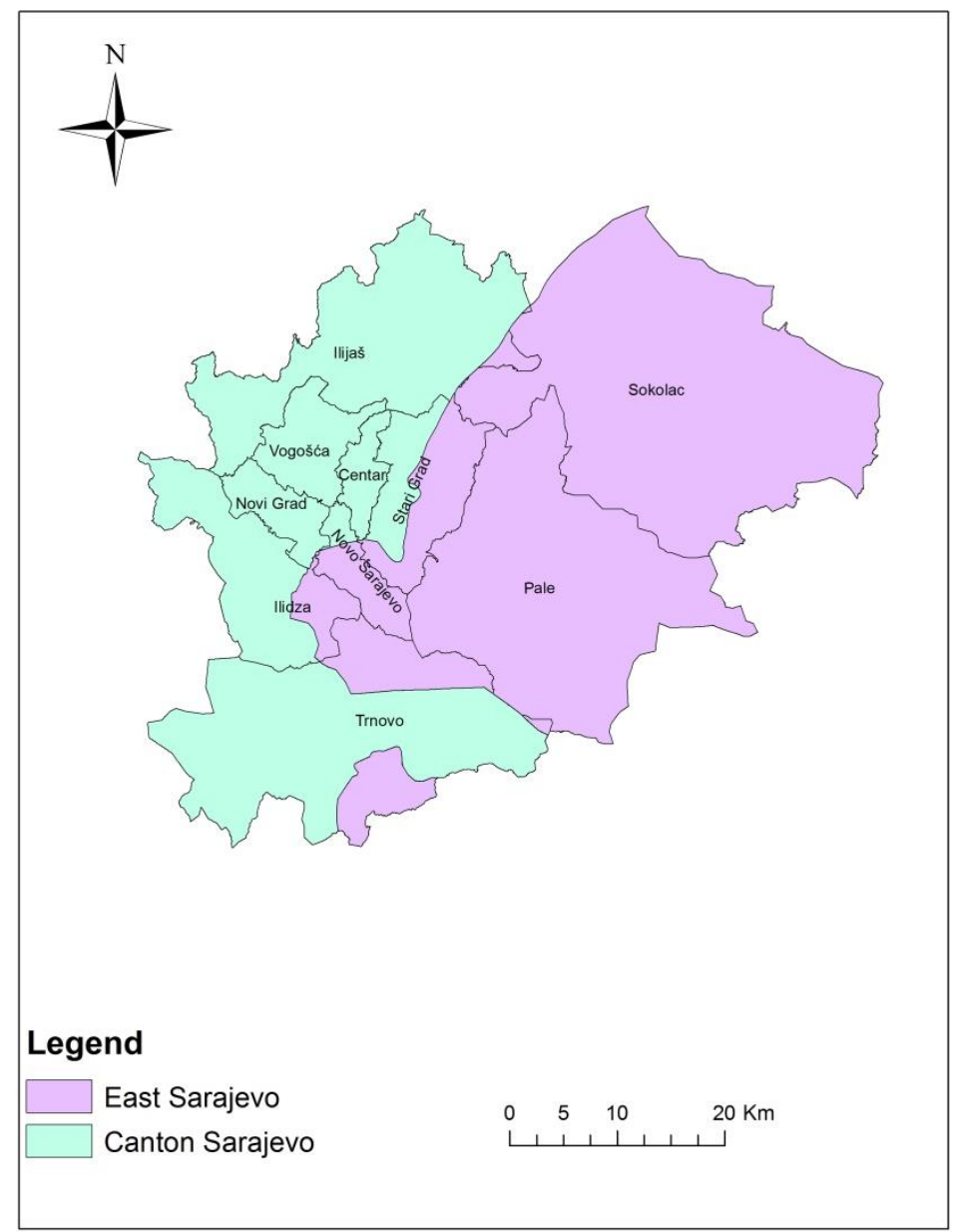

Figure 2. Area of city Sarajevo divided in to Kanton Sarajevo (FBH) and East Sarajevo (RS)

In the area of today's city of East Sarajevo there are 43 settlements which are divided after 1991 between the Republic of Srpska and the Federation of Bosnia and Herzegovina. In the Table 1 [1] one can analyze number of divided settlements, the total number of settlements of pre-war municipalities and the degree of disintegration which represents the ratio of the total number of settlements and divided settlements. 
Tabele 1. The number of divided settlements, number of settlements in 1991 Census and level of disintegration in the area of Sarajevo - East Sarajevo.

\begin{tabular}{lccc}
\hline \multicolumn{1}{c}{ Municipality } & $\begin{array}{c}\text { No. of divided } \\
\text { settlements }\end{array}$ & $\begin{array}{c}\text { No. of settlements } \\
\text { in 1991 }\end{array}$ & $\begin{array}{c}\text { Level of } \\
\text { disintegration }\end{array}$ \\
\hline Ilidza - East Ilidza & 2 & 14 & 14.3 \\
\hline Novi Grad - East Ilidza & 1 & 3 & 33.3 \\
\hline Stari Grad - East Stari Grad & 7 & 16 & 43.8 \\
\hline Ilijaš - East Stari Grad & 2 & 77 & 2.6 \\
\hline Novo Sarajevo - East Novo Sarajevo & 3 & 8 & 37.5 \\
\hline Pale RS - Pale FBH & 6 & 70 & 8.6 \\
\hline Olovo - Sokolac & 5 & 44 & 11.4 \\
\hline Trnovo FBH- Trnovo RS & 17 & 63 & 27.0 \\
\hline
\end{tabular}

The highest degree of disintegration in the investigated area is the municipality of Stari Grad, $43.8 \%$, or from 16 pre-war settlements 7 were divided to the newly created municipality of Istocni Stari Grad. This is followed by the municipality of Novo Sarajevo, which divides 3 of 8 settlements (37.5\%) with the municipality of East New Sarajevo. The municipality of Novi Grad has a degree of disintegration of $33.3 \%$ and Trnovo 27\%, while the lowest level has the municipality of Ilijaš, $2.6 \%$.

The disintegration processes of the settlement systems in the area of Sarajevo, and also in all Bosnia and Herzegovina, mostly influenced the settlements from the category of less than 2000 inhabitants. In the investigated area, 38 settlements, which belonged to the category of up to 2000 citizens, that is $88,4 \%$ of the settlements, while the remaining $11,6 \%$ belonged to the category of more than 2000 citizens, were divided between the two entities (Table 2 [1]).

Table 2. Classification of divided settlements in the area of Sarajevo - East Sarajevo based on the number of inhabitants according to the 1991 Census

\begin{tabular}{lcccccccccc}
\hline $\begin{array}{l}\text { Category of } \\
\text { settlement }\end{array}$ & \multirow{2}{*}{$0-49$} & $50-99$ & $\begin{array}{c}100- \\
199\end{array}$ & $\begin{array}{c}200- \\
499\end{array}$ & $\begin{array}{c}500- \\
999\end{array}$ & $\begin{array}{c}1000- \\
1999\end{array}$ & $\begin{array}{c}2000- \\
4999\end{array}$ & $\begin{array}{c}5000- \\
9999\end{array}$ & $19000-$ & $>20000$ \\
\hline No. of settl. & 13 & 8 & 4 & 10 & 0 & 3 & 1 & 0 & 0 & 4 \\
\hline Percent (\%) & 30.2 & 18.6 & 9.3 & 23.3 & 0.0 & 7.0 & 2.3 & 0.0 & 0.0 & 9.3 \\
\hline
\end{tabular}

But, if the number of citizens of the divided settlements is analyzed in more detail, it could be seen that the number of divided settlements from the category of less than 500 citizens is 35 , that is $81,4 \%$, that is, the most of the divided settlements are from the category of less than 50 citizens, $30,2 \%$, and from 200 to 500 citizens, $23,3 \%$. It is noted that the entity border in this area divided mostly rural settlements. In the category of divided urban settlements there are 4 settlements, which are also highly urbanized, with over 40000 citizens $^{4}$.

According to the census from 1991, 350010 citizens, which was $66,4 \%$ of the population of the city of Sarajevo, lived in the mentioned settlements which were divided by the entity border. Only 8185 inhabitants, that is $2,3 \%$, lived in rural settlements-less than 2 000 inhabitants, while 341825 inhabitants, that is $97,7 \%$ lived in five divided urban settlements-more than 2000 inhabitants.

\footnotetext{
${ }^{4}$ Settlements Sarajevo a part of Ilidza 63179 inhabitants, Sarajevo a part of Novi Grad 136321 inhabitants, Sarajevo a part of Stari Grad 48794 inhabitants and Sarajevo a part of Novo Sarajevo 90 892inhabitants .
} 
The surface of the city of Sarajevo was $2048 \mathrm{~km}^{2}$, it consisted of 10 boroughs and 340 settlements. From the total surface of the city of Sarajevo, $757 \mathrm{~km}^{2}$, that is $36,9 \%$ of its former territory, was given to the city of East Sarajevo.

According to the census from 2013, the city of East Sarajevo has a territory of 1449,2 $\mathrm{km}^{2}, 216$ settlements in 6 municipalities and 59916 inhabitants [2]. Canton Sarajevo in the Federation of Bosnia and Herzegovina has a territory of $1276,9 \mathrm{~km}^{2}, 244$ settlements in 9 municipalities.

For the sake of the comparison of the settlements and the understanding of what happened with the settlement system in the investigated area, both territorial units, Sarajevo in Federation of Bosnia and Herzegovina and East Sarajevo will be reduced to the pre-war administrative borders. This would mean that today, in the area of the pre-war city of Sarajevo, there are $379^{5}$ settlements, which is 39 more than in 1991. The average size of a settlement in 1991 was $6 \mathrm{~km}^{2}$, and today it is $5,4 \mathrm{~km}^{2}$.

Thanks to the data mentioned above, we can easily see the extent of disintegration processes in the area of the city of Sarajevo and East Sarajevo, and that it represents a great issue in comparing the data of the census from 1991 and 2013, because it is almost impossible to determine how many inhabitants of the divided settlements lived in the territory of Republic of Srpska and how many in the Federation of Bosnia and Herzegovina. The problem could be solved by the inspection of the census circles of the settlements. After speaking to the official institutions, the Agency for Statistics and the Federal Institute for Statistics, the answer was that every evaluation of the population in the census circles would be inaccurate because of the division of the census circles with the inter-entity line of border. The inter-entity line of border is $1146 \mathrm{~km}$ long and it was drawn in so called Dayton maps with the proportion 1:50 000, which means that its accuracy is $50 \mathrm{~m}$. It actually means that the inter-entity line is a zone $100 \mathrm{~m}$ wide, and it would be difficult to determine to which entity the population from this zone belong.

\section{CONCLUSION}

The border which divided the territory of Bosnia and Herzegovina into two entities, carries a number of negative consequences. The division, which was based primarily on political criteria, reflects negatively onto the possibility of normal functioning and development of a compact area.

The negative implications are a fact, a reflection of non-observance of the geographical regionalization [8], which was shown through the analysis of this issue on the example of the city of Sarajevo.

The lack of respect for the settlement systems and the administrative borders of the settlements led to the disintegration, the division between two entities, the creation of the "double" settlements, "unreasonable" divisions of the urban unity, where the border cuts the streets and a residential infrastructure (the settlement of Dobrinja). In the area of the former city of Sarajevo, 43 settlements were divided by the entity border. About $30 \%$ of the divided settlements are the settlements of less than 50 inhabitants, the rural settlements where depopulation and the disappearance of the settlements is expressed, and one of the reasons is the border line, for sure.

\footnotetext{
${ }^{5} 120$ settlements of East Sarajevo (excluding the settlements of municipality Sokolac) plus 244 settlements of Canton Sarajevo and 15 settlements of Pale FBH.
} 
Other than problems with the disintegration of landscape structure, functional connection of natural resources and manufacturing capacities, the center of economic development, there is also a problem of the comparison of the data about the population. There is a big problem with detail demographic analysis because it cannot be determined with precision how many inhabitants lived in the territory of RS and how may in FBH, according to the census from 1991.

\section{REFERENCES}

[1] Croatian Bureau of statistics Republic of Croatia. The population of Bosnia and Herzegovina-ethnic groups by settlements, Croatia, 1995.

[2] Institute of Statistics Republic of Srpska. Census of population. Households and dwellings in Republika Srpska - Census results by settlements, Republic of Srpska, 2017.

[3] Lukić Tanović, M. \&Pašalić, S. \& Golijanin, J. Demographic development of Bosnia and Herzegovina from the Otoman period till 1991 and the modern demographic problems, Procedia - Social and Behavioral Sciences, Vol. 120, pp 238-247, 2014.

[4] Mandić, M. Geospatial consequences of development of the Republic of Srpska in the context of the changes in settlement system, Demographic Politics of the Republic of Srpska-reality and needs, Republic of Srpska, Vol. 10, pp 53-70, 2015.

[5] Mirić, R. The influence of the contemporary political-territorial structure on the changes in the settlement system of Bosnia and Herzegovina with a special focus on the Sarajevo suburban settlement of Dobrinja, Annales for Istrian and Mediterranean Studies, Series Historia et Sociologia, Slovenia, vol. 16/1, pp 221-233, 2006.

[6] Musa, S. Arrangement of settlements in Bosnia and Herzegovina, Mostariensia, Bosna and Herzegovina, vol. 22, pp 81-99, 2005.

[7] Mutabdzija, G. Dobrinja, An example of an inadequate inter-entity demarcation and changes in function of the boundary, Faculty of Philosophy Collection of papers, Repuclic of Srpska, vol. 3-4, pp 429-439, 2002.

[8] Spahić, M. \& Jahić, H. Geographical regionalizations of Bosnia and Herzegovina in the light of Euro-Atlantic integrations, Acta geographica Bosniae et Herzegovinae, Bosna and Herzegovina, Vol. 1, pp 35-52, 2014.

[9] https://commons.wikimedia.org/wiki/Atlas_of_Republika_Srpska 